\title{
Studi Netnografi Pola Komunikasi Jaringan Komunitas Cryptocurrency Dogecoin di Twitter
}

\author{
Netnographic Study of Dogecoin Cryptocurrency Community \\ Network Communication Patterns on Twitter
}

\author{
Lady Joanne Tjahyana \\ Universitas Kristen Petra \\ Siwalankerto 121 - 131, Surabaya 60236 \\ Jawa Timur, Indonesia \\ e-mail : joanne@petra.ac.id
}

Submitted: 15-05-2021, Revised: 03-06-2021, Accepted: 03-07-2021, Published: 19-07-2021

doi: https://doi.org/10.33508/jk.v10i1.3188

\begin{abstract}
Dogecoin was a cryptocurrency that started as a meme coin. However, Dogecoin price has increased by $800 \%$ in January 2021 and soared to 400\% in April 2021. The skyrocketed price could not be separated from the support of Dogecoin community and top public profiles at Twitter. This research was conducted using digital netnography method to see communication pattern of Dogecoin community network at Twitter. The community targeted in this study consists of all Twitter's users that actively participated in discussions about Dogecoin. Data mining and data analysis were done using social network analysis tools which were Netlytic and Brand 24 from 1 April - 9 May 2021 during several important moments that happened in the community. The mined data was all conversation data using keyword "Doge". The research found communication network pattern that includes 5 interaction types in the community. The findings suggest that cryptocurrencies' developers should give convincing information to make communities wanted to hold a cryptocurrency. Furthermore, it is important to maintain community's members who give each other encouragement and support. Also, the developers could work with top public profiles to give confirmation and convincing information that could overcome community's anxiety regarding the high volatility of a cryptocurrency.
\end{abstract}

Keywords: Netnography, Cryptocurrency, Dogecoin, Twitter, Communication Network

\begin{abstract}
ABSTRAK
Cryptocurrency Dogecoin awalnya dianggap sebagai meme coin namun telah mengalami kenaikan nilai tukar sebanyak $800 \%$ pada Januari 2021 dan bertambah lagi sebesar $400 \%$ pada April 2021. Hal ini tidak lepas dari dukungan kuat dari komunitas cryptocurrency Dogecoin dan top public profiles pada media sosial Twitter. Penelitian ini menggunakan metode digital netnography untuk melihat pola komunikasi jaringan komunitas cryptocurrency Dogecoin di Twitter. Komunitas yang diteliti tidak terpusat pada akun komunitas tertentu namun meliputi seluruh akun Twitter yang aktif berdiskusi mengenai Dogecoin. Batasan penelitan adalah pada tanggal 1 April - 9 Mei 2021 bertepatan dengan beberapa peristiwa penting yang terjadi. Data yang digunakan adalah semua percakapan pada Twitter dengan kata kunci "Doge" dan diambil menggunakan social network analysis tools Brand24 dan Netlytic. Penelitian ini menemukan adanya 5 tipe interaksi yang merupakan pola komunikasi jaringan Dogecoin. Pola komunikasi yang ditemukan pada penelitian ini dapat memberikan masukan bagi pengembang Dogecoin dan cryptocurrency lainnya tentang pentingnya memberikan informasi yang dapat meyakinkan komunitas untuk tetap hold sebuah cryptocurrency. Kemudian pentingnya membina komunitas yang saling mendukung dan memberi semangat di antara anggota komunitas, dan pentingnya bekerjasama dengan top public profiles untuk memberikan keyakinan dan konfirmasi untuk mengatasi keresahan komunitas terkait volatility yang tinggi dari sebuah cryptocurrency.
\end{abstract}

Kata kunci: Netnografi, Cryptocurrency, Dogecoin, Twitter, Jaringan Komunikas 


\section{Latar Belakang}

Dogecoin adalah cryptocurrency yang diciptakan oleh Billy Markus dari Portland, Oregon dan Jackson Palmer dari Sydney, Australia pada tahun 2013 dengan menggunakan maskot anjing Shiba Inu dan pada awalnya hanya dianggap sebagai meme coins atau joke (Chohan, 2017). Meskipun hanya dianggap sebagai gurauan namun Dogecoin telah mencapai kepopularitasan pada bulan Januari 2021 yang ditandai dengan meningkatnya nilai tukar sebesar $800 \%$ (Voell \& Reynolds, 2021). Melonjaknya nilai tukar Dogecoin tersebut diawali dengan komunitas cryptocurrency pada forum Reddit yang ramai membicarakan dan memberikan dukungan kepada Dogecoin (Irwan \& Indrawan, 2021). Terdapat pula dukungan dari beberapa public figure ternama seperti Elon Musk, Snoop Dog, dan Gene Simmons pada komunitas cryptocurrency di Twitter (Chohan, 2017). Meningkatnya popularitas Dogecoin terus berlanjut hingga terus mengalami pelonjakan nilai tukar pada bulan April 2021, tepatnya pada tanggal 15 April 2021 ketika Elon Musk mengepos tweet gambar internet meme Dogecoin dengan teks "Doge Barking at the Moon Miro" yang disusul dengan kenaikan nilai tukar Dogecoin sebanyak 400\% (Browne, 2021a). Tweet dari public figure lain seperti Mark Cuban juga telah memberikan pengaruh signifikan kepada lonjakan nilai tukar Dogecoin (Browne, 2021b).

Fenomena Dogecoin ini dianggap sebagai contoh klasik dari greater fool theory di mana para investor membeli cryptocurrency bukan karena nilai sesungguhnya namun karena mengandalkan banyaknya investor lain yang akan bersama - sama menimbun dan menaikkan nilai tukar sebuah cryptocurrency dan dapat berakibat terciptanya kondisi bubble yang dapat menambah resiko kerugian investor
(Kimberley dikutip dalam Browne, 2021a). Meskipun terdapat resiko bubble, Aslantas (2021) menyatakan bahwa komunitas Dogecoin tetap menikmati trend dan mengikuti hype dari cryptocurrency tersebut dengan terlibat aktif dalam postingan baik berupa dukungan maupun bersenang - senang dengan meme Dogecoin di media sosial. Adapun hype Dogecoin yang secara konstan terjadi pada komunitas justru diperlukan untuk mempertahankan dan menaikkan nilai Dogecoin (Aslantas, 2021).

Nilai tukar Dogecoin juga sempat mengalami penurunan sebesar $20 \%$ yang justru terjadi pada saat Doge Day pada tanggal 20 April 2021 setelah sebelumnya hype dari komunitas dalam menyambut hari perayaan Dogecoin telah viral dengan hashtag \#DogeDay (Murdock, 2021). Meskipun terjadi penurunan nilai tukar pada hari perayaan Dogecoin tersebut, namun komunitas tetap antusias dalam mengepos dukungan, semangat dan keyakinan mereka terhadap Dogecoin (Wilson, Irrera, \& Chavez-dreyfuss, 2021).

Komunitas Dogecoin merupakan komunitas dengan jenis interest communities yaitu komunitas yang mendiskusikan suatu topik tertentu sesuai dengan ketertarikan dari masing - masing anggotanya (Laudon dan Traver, dikutip dalam Priyowidodo, 2019). Selain itu, komunitas Dogecoin yang ada di Twitter merupakan komunitas virtual yaitu komunitas yang melibatkan sekelompok orang yang mempunyai ketertarikan yang sama terhadap sebuah topik dan berkomunikasi secara termediasi melalui media berbasis internet (Lizzo \& Liechty, 2020). Komunitas virtual dapat menyatukan anggota dengan pola pikir yang sama tanpa memedulikan batasan geografis dan demografis (Pathak \& Pathak-Shelat, 2017). 
Komunikasi dan interaksi yang berkualitas dalam sebuah komunitas virtual dapat membangun koneksi emosional yang berlanjut kepada terciptanya sense of community (Gibbs, $\mathrm{Kim}, \& \mathrm{Ki}$, 2019). Selain itu semakin besar frekuensi komunikasi dan interaksi yang terjadi dalam komunitas virtual maka semakin kuat pula sense of community yang terbentuk (Dawson dikutip dalam Chatterjee \& Correia, 2020). Terdapat 4 faktor dalam sebuah komunitas yang dapat membangun sense of community yaitu membership, influence, integration and fulfillment of needs, dan shared emotional connection (McMillan \& Chavis dikutip dalam Lizzo \& Liechty, 2020). Faktor faktor tersebut dapat digunakan pula untuk melihat sense of community pada interaksi yang ada pada komunitas virtual. (Lizzo \& Liechty, 2020).

Menurut Gruzd, Paulin, \& Haythornthwaite (2016) analisis jaringan komunikasi dapat digunakan untuk melihat struktur jaringan komunikasi dengan berfokus kepada karakteristik jaringan seperti aliran informasi, peran, posisi, hubungan, struktur sosial, bahasa, style dan norma serta topik yang dibicarakan dalam sebuah komunitas. Eriyanto (2014) menyatakan bahwa analisis jaringan komunikasi menggambarkan interaksi dan relasi dalam bentuk garis diantara setiap titik anggota jaringan yang disebut sebagai nodes. Pada media sosial seperti Twitter, nodes adalah akun - akun Twitter dan edges adalah relasi yang terbentuk di antara nodes (Bright, 2018). Selain itu, jaringan komunikasi dapat dianalisa dengan melihat interaksi antar nodes dalam bentuk mention, reply, retweet, dan quote (Eriyanto, 2014). Kemudian terdapat pula beberapa properti yang dapat diukur untuk menganalisa struktur sebuah jaringan komunikasi, diantaranya yaitu kepadatan (density), mutualitas (reciprocity), sentralisasi (centralization), diameter dan jarak (distance) serta modularitas (modularity) (Eriyanto, 2014; Gruzd et al., 2016).

Menurut Tjahyana (2020), dalam sebuah jaringan komunikasi terdapat dominant actor yang berperan dalam menggerakan opini dan trend percakapan. Pada media sosial seperti Twitter, dominant actor yang lebih dikenal dengan sebutan influencers memiliki peran dalam memengaruhi dan menggerakan opini dalam sebuah komunitas dengan pendekatan yang yang sesuai dengan budaya dan kebiasaan pada komunitas tersebut (Tjahyana, 2020).

Twitter adalah media sosial yang seringkali dianggap sebagai tempat untuk mendapatkan data terkait prediksi aset keuangan, termasuk cryptocurrency (Phillips \& Gorse, 2018). Menurut Phillips \& Gorse (2018), data prediksi keuangan tersebut dapat berupa sentimen negatif dan positif maupun sentimen yang menunjukkan ketidakpastian terhadap nilai sebuah cryptocurrency. Sentimen yang ada dapat terlihat dari postingan berupa berita, komentar, dan informasi resmi terkini seputar cryptocurrency (Park \& Lee, 2019).

Phillips \& Gorse (2018) menemukan bahwa sebagian besar pengguna Twitter yang aktif dalam diskusi cryptocurrency menggunakan media sosial Twitter hanya karena ingin mengikuti perkembangan prediksi cryptocurrency. Hal ini dapat dilihat dari banyaknya profil akun Twitter yang terlibat dalam komunitas cryptocurrency tidak mengepos topik selain cryptocurrency dan akun Twitter hanya mereka gunakan untuk mencermati dan berdiskusi mengenai cryptocurrency (Hernadez et. al dikutip dalam Phillips \& Gorse, 2018).

Dalam mengepos percakapan dalam bentuk tweet, komunitas cyrptocurrency juga menggunakan hashtags dalam bentuk simbol \# untuk mengkategorikan 
percakapan ke dalam kategori tertentu berdasarkan jenis dan nama dari cryptocurrency (Abraham, Higdon, Nelson, \& Ibarra, 2018). Contoh penggunaan hashtags untuk untuk cryptocurrencies adalah \#BTC untuk Bitcoin, dan \#ETH untuk Etherium (Abraham et al., 2018).

Media sosial Twitter juga menyediakan cashtags untuk mempromosikan topik diskusi dan informasi seputar keuangan, seperti stocks dan cryptocurrencies (Mirtaheri, Abu-El-Haija, Morstatter, Steeg, \& Galstyan, 2019). Cashtags tersebut berupa simbol \$ untuk menyebutkan nama sebuah cryptocurrency yang diletakkan pada awalan simbol cyptocurrency tersebut, seperti \$BTC untuk Bitcoin (Mirtaheri et al., 2019).

Terdapat beberapa penelitian yang telah dilakukan sebelumnya terkait komunitas cryptocurrency seperti penelitian yang dilakukan oleh Tana, Breidbach, \& Turpin dengan judul " I Want a Lamborghini: An Ethnography of Cryptocurrency Communities". Penelitian tersebut menggunakan metode etnografi untuk melihat peran dan fungsi masing masing anggota yang ada pada komunitas cryptocurrency. Penelitian dilakukan dengan menghadiri dan observasi pertemuan tatap muka yang dilakukan oleh komunitas secara rutin pada sebanyak 14 kali pertemuan sepanjang tahun 2017 di Melbourne, Australia. Dari hasil penelitian tersebut didapatkan adanya beberapa peran dan fungsi pada komunitas seperti knowledge - seeker, visionary, novice, dan fortune hunter (Tana, Breidbach, \& Turpin, 2019).

Kemudian terdapat pula beberapa penelitian mengenai prediksi nilai cryptocurrency melalui pantauan sentiment analysis pada media sosial, seperti penelitian yang dilakukan oleh Kraaijeveld \& De Smedt (2020) dengan judul "The predictive power of public Twitter sentiment for forecasting cryptocurrency prices". Penelitian tersebut memantau dan mengambil data sentimen komunitas cryptocurrency pada periode Juni - Agustus 2018. Kemudian dilakukan perbandingan sentimen dengan pergerakan nilai 9 cryptocurrencies terbesar pada saat itu. Hasil penelitian tersebut menyatakan bahwa perhitungan casualty test, bullishness ratio, dan tweet volume membuktikan bahwa sentimen komunitas dapat digunakan untuk memprediksi nilai cryptocurrency. Selain itu terdapat pula penelitan yang dilakukan oleh Zhu et al. (2018) berjudul "Twitter Sentiment Analysis For Bitcoin Price Prediction" di mana penelitian tersebut melihat hubungan antara sentimen dengan prediksi harga dari cryptocurrency Bitcoin. Hasil dari penelitian tersebut menyatakan bahwa terdapat hubungan yang kuat antara kekuatan sentimen dengan prediksi harga Bitcoin (Zhu et al., 2018).

Selanjutnya terdapat penelitian jarinngan komunikasi cryptocurrency yang dilakukan oleh Park \& Lee (2019) dengan judul " How Are Twitter Activities Related To Top Cryptocurrencies' Performance? Evidence From Social Media Network And Sentiment Analysis". Penelitian tersebut tidak hanya melihat pengaruh sentimen namun juga melihat pengaruh interaksi di dalam jaringan komunikasi pada media sosial terhadap performa 74 cryptocurrencies terbaik pada saat itu (Park \& Lee, 2019). Penelitian tersebut menemukan bahwa semakin besar koneksi indegree yang didapat oleh sebuah akun media sosial resmi dari sebuah cryptocurrency maka semakin tinggi pula performa dari cryptocurrency tersebut (Park \& Lee, 2019). Selain itu Park \& Lee (2019) juga menyatakan bahwa interaksi berupa reply-mentioning bertujuan untuk memperkuat jaringan komunikasi sebuah cryptocurrency dengan cara 


meminimalisasi sentimen yang

mengandung ketidakpastian dan memberikan rasa aman terutama kepada para investor yang baru bergabung.

Berdasarkan beberapa penelitian sebelumnya maka terdapat research gap yang mendasari penelitian ini. Penelitian yang dilakukan oleh Tana et al. (2019) menggunakan metode etnografi dan lokasi penelitian adalah pertemuan offline yang dilakukan oleh komunitas cryptocurrency, sedangkan penelitian ini menggunakan metode netnografi yang merupakan pengembangan etnografi. Selain itu perbedaan berikutnya terletak pada lokasi penelitian, di mana penelitian ini dilakukan sepenuhnya secara online di dalam komunitas virtual pada Twitter tanpa terbatas ruang dan waktu untuk bertatap muka. Kemudian penelitan yang dilakukan oleh Kraaijeveld \& De Smedt (2020) dan Zhu et al. (2018) hanya menganalisa kekuatan prediksi nilai cryptocurrency berdasarkan sentimen komunitas, namun tidak melihat pola interaksi komunitas cryptocurrency pada Twitter. Selain itu penelitian yang dilakukan oleh Park \& Lee (2019) meneliti pengaruh interaksi jaringan komunikasi pada performa cryptocurrency menggunakan data media sosial Twitter untuk 74 cryptocurrency terbaik saat itu. Sedangkan penelitian ini akan fokus kepada pola interaksi jaringan cryptocurrency Dogecoin saja.

Berdasarkan fenomena Dogecoin dan hype yang terjadi pada komunitas, serta untuk menjawab research gap yang ditemukan dengan penelitian sebelumnya terkait komunitas cryptocurrency, maka penelitian ini bertujuan untuk melihat pola komunikasi jaringan komunitas cryptocurrency Dogecoin pada media sosial Twitter. Park \& Lee (2019) menyatakan bahwa banyak perusahaan cryptocurrency yang menggunakan media sosial sebagai sarana promosi, penyebaran informasi, dan memfasilitasi aktifitas dan diskusi pada komunitas yang bertujuan untuk membuat para investor semakin yakin akan masa depan dari cryptocurrency tersebut. Oleh karena itu penelitian ini berkontribusi dalam memberikan gambaran bagi developer \& influencers Dogecoin dan cryptocurrency tentang pola interaksi dan komunikasi komunitas cryptocurrency agar dapat membuat strategi pemasaran yang tepat. Selain itu penelitian ini memberikan kontribusi akademis dalam memperkaya studi netnografi khususnya dalam jaringan komunikasi di media sosial terkait komunitas cryptocurrency.

\section{Metode}

Komunitas Dogecoin pada Twitter yang dituju pada penelitan ini tidak terbatas pada komunitas yang terbentuk dan terpusat pada akun tertentu, namun keseluruhan komunitas Dogecoin pada Twitter yang terdiri dari semua akun komunitas maupun akun individual yang aktif berdiskusi dengan topik seputar Dogecoin. Untuk memahami pola interaksi dan komunikasi yang ada pada komunitas Dogecoin pada Twitter maka penelitian ini menggunakan metode netnografi. Netnografi digunakan sebagai pendekatan untuk memahami dinamika sosial yang terjadi di dalam komunitas virtual (Pathak \& Pathak-Shelat, 2017). Penelitian ini khususnya berfokus kepada tipologi netnografi digital, yaitu metode yang berfokus kepada fenomena global dan menggunakan analisa teknis dan data statistik untuk mendeteksi pola dan memahami interaksi yang ada. (Kozinets, 2018; Morais, Santos, \& Gonçalves, 2020).

Proses netnografi dapat dibagi menjadi beberapa tahap yaitu tahap perencanaan penelitian dan cultural entrée, pengumpulan dan interpretasi data, memastikan standar etika, dan 
representasi penelitian (Kozinets, dikutip dalam Del Vecchio, Mele, Passiante, Vrontis, \& Fanuli, 2020).

Pada tahap perencanaan penelitian dan cultural entrée peneliti menetapkan konteks dan tujuan dari proses netnografi yang akan dilakukan. Peneliti sebagai netnografer telah terlibat dan melakukan observasi komunitas sejak Februari 2021 dengan fokus pengambilan data pada antara 1 April - 9 Mei 2021. Rentang waktu tersebut dipilih karena terdapat beberapa peristiwa penting pada komunitas Dogecoin terutama terkait dengan hype yang terjadi dan adanya lonjakan nilai tukar Dogecoin.

Sedangkan untuk pengumpulan dan interpretasi data akan bersumber dari diskusi yang terjadi pada komunitas cryptocurrency Dogecoin di Twitter. Data yang diambil adalah semua data percakapan yang menggunakan kata kunci "Doge". Penelitian ini menggunakan social network analysis tools untuk menarik data percakapan yaitu Brand24 dan Netlytic. Menurut Del Vecchio et al. (2020) Brand24 merupakan social media monitoring tools yang dapat memberikan data statistik media sosial secara konsisten dalam jangka waktu tertentu. Netlytic adalah social network analysis tools yang dapat digunakan untuk melakukan data mining berupa percakapan pada media sosial dan dapat memberikan visualisasi jaringan komunikasi berdasarkan jenis interaksi dan topik (Gruzd et al., 2016). Selain itu Netlytic juga dapat digunakan untuk melihat data stuktur jaringan seperti diameter, density, reciprocity, centralization dan modularity (Tjahyana, 2020). Kemudian proses interpretasi data akan didasarkan pada konsep komunitas virtual, sense of community, pola dan struktur jaringan komunikasi, serta elemen budaya pada komunitas.
Untuk memastikan penelitian ini tidak menyalahi standard etika, maka seperti yang diusulkan oleh Annisa (2019), peneliti memastikan bahwa akun yang akan disebutkan dalam publikasi penelitian ini adalah akun yang bersifat public. Jika akun tersebut adalah akun public maka pada dasarnya akun beserta seluruh isi tweet yang ada dapat dilihat dan diakses oleh semua orang baik dari dalam Twitter maupun melalui mesin pencari seperti Google ("Who Can See Your Tweets Twitter Privacy and Protection Settings," 2021).

Penelitian ini akan merepresentasikan pola jaringan komunikasi komunitas cryptocurrency Dogecoin yang ada di Twitter, dengan melihat data struktur jaringan, sense of community, dan beberapa elemen budaya seperti bahasa dan kebiasaan yang ada pada komunitas.

\section{Pembahasan}

Algoritma Twitter tidak membatasi pengguna hanya melihat tweets dari akun yang di-follow, namun pengguna juga dapat dengan mudah melihat semua tweets terkini tentang topik yang di-follow pada halaman home pengguna. Update tersebut meliputi tweets yang terkini maupun yang terpopuler pada sebuah topik yang diikuti. Selain itu pengguna juga dapat dengan mudah menemukan tweets terkini dan terpopuler berdasarkan kata kunci dan hashtags tertentu. Algoritma Twitter juga akan merekomendasikan tweets sesuai dengan topik yang disukai oleh pengguna (Gotter, 2019).

Lebih lanjut pengguna juga dapat berinteraksi dengan pengguna lain yang mengepos tweet mengenai topik yang diikuti dengan cara like, reply, retweet, quote, dan mention. Tentu saja interaksi hanya dapat dilakukan dengan pengguna yang memiliki tipe akun public. Sehingga 
interaksi komunitas yang terbentuk pada Twitter tidak terbatas pada akun - akun tertentu saja (Gotter, 2019).

Demikian pula dengan komunitas cryptocurrency Dogecoin pada Twitter, terdiri dari pengguna Twitter yang dapat bertemu dan saling berinteraksi satu sama lain dengan bebas tanpa harus mengikuti akun - akun tertentu. Interaksi tersebut terjadi ketika pengguna melihat rekomendasi tweet terkini dan terpopuler dari topik Dogecoin dan memutuskan untuk berinteraksi dalam bentuk like, reply, mention, quote dan retweet. Setelah itu pengguna dapat memutuskan untuk follow akun - akun tertentu untuk memastikan mereka tidak tertinggal update dari percakapan yang diikuti.

Agar tweet seorang pengguna mengenai Dogecoin dapat muncul sebagai rekomendasi terkini atau terpopuler, diperlukan adanya kata kunci seputar Dogecoin atau memberikan hashtags dan cashtags Dogecoin pada tweet yang dipos. Oleh karena itu agar dapat tergabung dan berinteraksi dengan komunitas Dogecoin pada Twitter tidak diperlukan adanya keanggotaan khusus yang terpusat pada akun tertentu. Jika seorang pengguna mengepos tweet dengan kata kunci, hashtags dan cashtags seputar Dogecoin, maka pengguna tersebut dapat terlibat dan berinteraksi di dalam komunitas Dogecoin pada Twitter.

Adapun dari proses data mining yang dilakukan dengan tools Brand24, didapatkan sejumlah 574.688 mentions berbahasa Inggris pada media sosial Twitter dengan kata kunci "Doge" pada rentang waktu tanggal 1 April - 9 Mei 2021. Kemudian Brand24 digunakan untuk melakukan kategorisasi data dan text analysis berdasarkan kata kunci dan hashtags. Selain itu Brand 24 digunakan untuk mendapatkan data para influencers seputar topik Dogecoin.
Berdasarkan observasi netnografer, tweets yang diposting pada komunitas memiliki motivasi tertentu sesuai dengan faktor - faktor yang ada prinsip sense of community. Penggunaan hashtags, cashtags dan katakunci tertentu menunjukkan motivasi dari tweets tersebut. Temuan dan analisa kata kunci ini sesuai dengan pernyataan Kozinets (2018) bahwa insight yang didapatkan dari netnografi dapat meliputi elemen - elemen budaya seperti penggunaan bahasa, ritual, peran, identitas, nilai, cerita, mitos, dan arti yang tersirat.

\section{Pola Komunikasi Berdasar Konsep Sense of Community}

Lizzo \& Liechty (2020) menemukan bahwa faktor membership yang muncul dalam sense of community ditandai dengan penggunaan simbol, kalimat, ataupun kata yang merupakan keunikan dari sebuah komunitas. Hal ini juga merupakan ekspresi dari rasa bangga menjadi bagian dari sebuah komunitas, dan merupakan cara untuk berbagi pengalaman dengan anggota komunitas yang lain (Lizzo \& Liechty, 2020). Dalam berinteraksi, komunitas Dogecoin pada Twitter menggunakan beberapa hashtags dan cashtags serta kata kunci untuk menunjukkan kebanggaan mereka menjadi bagian dari komunitas Dogecoin. Seperti yang terlihat pada Tabel 1, terdapat hashtags yang disertakan dalam tweets yang diposting oleh anggota komunitas. Hashtags yang banyak digunakan adalah \#Doge, \#Dogecoin, dan \#Dogearmy yang bertujuan untuk memberikan identitas dan memperkenalkan diri sebagai bagian dari komunitas Dogecoin. Komunitas Dogecoin terdiri dari investor cryptocurrency dari seluruh dunia dan meskipun tidak saling mengenal namun dengan menggunakan hashtags tersebut pada tweets, maka mereka akan dikenali sebagai bagian dari 
komunitas. Hal ini sesuai dengan pernyataan (Naranjo-Zolotov, Oliveira, Casteleyn, \& Irani, 2019) tentang prinsip membership pada komunitas virtual, di mana anggota komunitas akan merasa menjadi bagian dari sebuah komunitas meskipun tidak saling mengenal satu sama lainnya sebelumnya.

Selain itu, penggunaan cashtags $\$$ Doge dan $\$$ Dogecoin seperti yang terlihat pada Tabel 2, mengindikasikan bahwa selain ingin dikenal sebagai bagian dari komunitas Dogecoin, mereka juga ingin dikenal sebagai bagian dari komunitas yang lebih luas, yaitu komunitas yang tergabung dalam topik finance pada Twitter. Sesuai dengan fungsi penggunaan cashtags yaitu agar pengguna Twitter dapat dikenal dan terlibat dalam berbagai diskusi seputar finance yang tentunya tidak terbatas pada topik cryptocurrency saja (Evans, Owda, Crockett, \& Vilas, 2019).

Tabel 1 Jumlah mentions berdasarkan hashtags populer

\begin{tabular}{ll}
\hline Hashtags & $\begin{array}{l}\text { Jumlah } \\
\text { mentions }\end{array}$ \\
\hline \#Doge & 266.041 \\
\#Dogecoin & 130.939 \\
\#Dogearmy & 40.623 \\
\#Dogecointothemoon & 31.986 \\
\#Dogecoinrise & 24.551 \\
\#Dogeday & 21.208 \\
\#Dogecoins & 14.033 \\
\#Dogetothemoon & 11.797 \\
\#Dogefather & 11.404 \\
\hline
\end{tabular}

Sumber : Hasil penelitian menggunakan tools Brand24

Tabel 2 Jumlah mentions berdasarkan cashtags populer

\begin{tabular}{ll}
\hline Cashtags & $\begin{array}{l}\text { Jumlah } \\
\text { mentions }\end{array}$ \\
\hline \$doge & 196.050 \\
\$dogecoin & 467 \\
\hline
\end{tabular}

Sumber : Hasil penelitian menggunakan tools
Penggunaan cashtags tersebut juga menunjukkan adanya faktor influence dalam sense of community yaitu adanya keinginan untuk memberikan pengaruh tidak hanya di dalam komunitas itu sendiri namun juga menjangkau dunia di luar komunitas yang lebih luas (Lizzo \& Liechty, 2020). Dalam konteks komunitas Dogecoin, mereka yang menggunakan tidak hanya hashtags sebaga indentitas, namun juga menggunakan cashtags, dapat dikatakan ingin berkontribusi dan memberikan pengaruh lebih luas pada komunitas cryptocurrency dan finance pada umumnya.

Menurut Klein, Pham Thu, \& Walther (2018), cryptocurrency memiliki volatility yang tinggi dibanding aset lain seperti emas. Volatility yang tinggi ini ditandai secara terus menerus dengan adanya penurunan nilai tukar secara drastis sehingga para investor dapat mengambil keuntungan sebesar - besarnya pada saat pergerakan nilai tukar berada di puncak. Selain itu tingginya volatility juga disebabkan adanya perisitiwa ataupun perubahan regulasi dan legalitas dari cryptocurrency (Klein et al., 2018).

Dogecoin juga memiliki volatility yang tinggi dan pergerakan nilai tukar tidak hanya ditentukan oleh perilaku investor yang ingin mengambil keuntungan ataupun regulasi yang ada, namun juga oleh issue yang digerakkan oleh public profiles pada media sosial seperti beberapa tweet dari Elon Musk yang selalu disusul dengan kenaikan nilai tukar Dogecoin (Chohan, 2017). Tingginya volatility ini tentunya dapat membawa kekhawatiran pada para investor Dogecoin, meskipun sebenarnya volatility juga membuka kesempatan untuk mendapatkan keuntungan terutama bagi investor yang menyukai scalping atau swing trading. 
Lebih lanjut, komunitas Dogecoin pada Twitter menjadi tempat bagi para investor untuk mencari informasi seputar issue terkini, pergerakan nilai tukar Dogecoin dan tentu saja memantau tweets terkini dari para public profiles dan influencers Dogecoin. Selain itu para investor juga mencari konfirmasi dan prediksi nilai tukar serta waktu yang tepat untuk menjual dan membeli Dogecoin.

Komunitas Dogecoin pada Twitter menjadi tempat yang tepat untuk mencari semua informasi dan konfirmasi tersebut, karena banyaknya tweets baik dari top public profiles dan influencers maupun dari masing - masing anggota komunitas yang berbagi pengalaman dan memberikan semangat. Selain itu, komunitas Dogecoin menjadi tempat untuk mencurahkan emosi dan perasaan, terutama jika mendapatkan keuntungan ketika nilai tukar Dogecoin mengalami kenaikan ataupun kerugian yang diakibatkan dari penurunan drastis nilai tukar Dogecoin secara mendadak. Hal ini sesuai dengan faktor integration and fulfillment of needs serta shared emotional connection pada sense of community di mana anggota komunitas saling memenuhi kebutuhan, berbagi serta mencurahkan perasaan dan emosi (Lizzo \& Liechty, 2020).

Penggunaan hashtags dan kata kunci tertentu menjadi penanda bahwa para investor yang juga adalah anggota komunitas Dogecoin saling berbagi pengalaman, perasaan dan dukungan satu sama lainnya. Seperti terlihat pada Tabel 1 terdapat hashtags populer yang digunakan untuk memberi semangat seperti \#Dogecointothemoon dan \#Dogecoinrise, yang memberikan semangat bahwa nilai tukar Dogecoin akan mengalami kenaikan yang sangat tinggi. Kemudian dapat juga dilihat pada Tabel 3 adanya kata kunci populer seperti moon, buy, pump, hold, hodl, mars, dan dip yang digunakan untuk memberikan semangat dan dukungan untuk membeli dan bertahan menjadi holder dari Dogecoin. Terdapat juga kata kunci SNL dan hashtags \#Dogefather, yang terkait dengan tweets dari Elon Musk bahwa ia akan menjadi host dari acara Saturday Night Live (SNL) pada tanggal 8 Mei 2021 dan pada saat itu ia akan membicarakan mengenai \#Dogefather.

"The Dogefather SNL May 8" (Elon Musk, 2021a)

Tweet tersebut mendapat sambutan yang luar biasa dari komunitas, dan banyak tweet yang menggunakan kata kunci SNL dan hashtags \#Dogefather dengan tujuan untuk memberikan semangat dan harapan bahwa pada acara tersebut akan menjadi peristiwa penting untuk cryptocurrency Dogecon.

Terdapat pula kata kunci SpaceX yang cukup banyak dipakai dalam tweets, sebagai antusiasme dari komunitas terhadap tweet Elon Musk pada tanggal 9 Mei 2021, yaitu sehari setelah penampilannya di SNL.

"SpaceX launching satellite Doge-1 to the moon next year

- Mission paid for in Doge

- 1st crypto in space

- 1st meme in space

To the mooooonnn!!"

(Elon Musk, 2021b)

Pada tweet tersebut Elon Musk mengumumkan bahwa SpaceX, perusahaan roket komersial miliknya, akan menerima Dogecoin sebagai salah satu alat pembayaran. Hal ini tentunya memberikan nilai tambah kepada Dogecoin sebagai sebuah cryptocurrency yang telah diperhitungkan secara serius. Penggunaan kata kunci SpaceX tentunya dimaksudkan untuk menjadi penyemangat dan harapan kepada semua investor bahwa Dogecoin tidak lagi menjadi meme coins dan akan mengalami peningkatan nilai tukar. 
Tabel 3 Jumlah mentions berdasarkan kata kunci populer

\begin{tabular}{ll}
\hline Kata Kunci & $\begin{array}{l}\text { Jumlah } \\
\text { mentions }\end{array}$ \\
\hline doge & 574.688 \\
moon & 105.199 \\
buy & 53.160 \\
pump & 30.510 \\
hold & 23.342 \\
sell & 17.971 \\
hodl & 17.769 \\
spaceX & 15.916 \\
give & 14.247 \\
SNL & 12.376 \\
mars & 10.806 \\
dip & 8.887 \\
\end{tabular}

Sumber : Hasil penelitian menggunakan tools Brand24

Kemudian terdapat pula hashtag \#Dogeday, yang mengajak para komunitas untuk menantikan Doge Day, yaitu perayaan hari Dogecoin pada tanggal 20 April 2021. Tentunya komunitas sangat antusias menyambut Doge Day dan banyak tweets yang berisi harapan bahwa Dogecoin akan mengalami pelonjakkan nilai tukar pada hari itu. Namun sayangnya kenyataan yang terjadi justru sebaliknya, karena mendekati Doge Day, justru nilai tukar Dogecoin mengalami penurunan 20\% (Murdock, 2021). Berdasarkan data yang ditemukan dari penelitian ini, justru saat penurunan nilai tersebut banyak anggota komunitas dan juga public profiles dan influencers yang memberikan semangat agar investor tetap hold atau hodl dan tidak dump atau sell Dogecoin mereka. Bahkan terdapat ajakan untuk justru buy di saat posisi dip. Itulah sebabnya kata kunci hold, hodl, dump, sell dan dip menjadi populer pada saat itu. Seperti Tweet dari seorang podcaster dan influencer Ben Baller mengandung ajakan dan semagat bagi para investor untuk tetap hodl Dogecoin.

\author{
"YALL THOUGHT I SOLD!!! \\ NO I DID NOT. EVEN AFTER WE HIT \$1.00 \\ USD I WILL NOT SELL! \\ 1. \#HODL \\ 2. Coinbase will pick up \#Doge \\ 3. Elon will take a \#Dogecoin to the moon. \\ 4. We aiming for over $\$ 1.00$ \\ \#DogeArmy stop playing! Everyone HODL! \\ (BEN BALLER ${ }^{\mathrm{TM}}$, 2021)
}

Kata kunci hodl sebenarnya adalah kesalahan ejaan yang disengaja dari kata hold dan merupakan salah satu kata kunci yang populer pada komunitas cryptocurrency. Hold adalah singkatan dari "hold on for dear life". Arti yang terkandung dari hodl adalah tetap mempertahankan sebuah cryptocurrency dan tidak menjual dalam kondisi apapun (Frankenfield, 2020). Ajakan untuk hodl tersebut tentunya memberikan pesan bahwa Dogecoin adalah cryptocurrency yang berharga untuk dipertahankan serta memiliki masa depan yang menjajikan.

Sedangkan kata kunci dip yang juga sering dipakai untuk memberikan semangat di saat nilai tukar mengalami penurunan, sebenarnya merupakan bagian dari frasa "buy the dips" yang artinya membeli di saat nilai sebuah cryptocurrency mengalami penurunan, sehingga nantinya akan mendapat keuntungan yang lebih banyak ketika nilai tukar berada di posisi puncak (Mitchell, 2021). Seperti terlihat pada tweet dari seorang influencer Dogecoin dengan akun @Dogecoin.

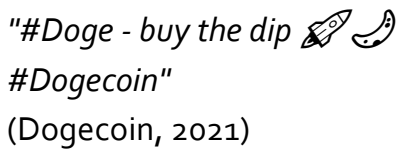

Tentunya kata kunci dip ini dipakai untuk memberikan semangat dan harapan agar tidak menjual bahkan justru membeli saat nilai tukar Dogecoin berada di posisi rendah karena adanya keyakinan bahwa nantinya nilai tukar tersebut akan kembali 
pada posisi puncak dan memberikan keuntungan besar.

Selain merupakan cryptocurrency dengan volatility yang tinggi, Dogecoin juga dianggap akan mengalami penurunan ketika antusiasme dari komunitas memudar sementara belum ada institusi dan developer yang mengadopsi dan menggarap Dogecoin dengan lebih serius (Pound, 2021). Oleh karena itu banyak public profiles dan influencers yang menggunakan pengaruh mereka untuk mencegah investor menjual Dogecoin. Seperti terlihat pada Tabel 4, terdapat top public profiles menurut data dari Brand 24 yang memiliki voice of share dan influences tertinggi.

Tabel 4 Top 10 Public Profiles Komunitas Dogecoin pada Twitter

\begin{tabular}{lll}
\hline Public Profiles & $\begin{array}{l}\text { Voice } \\
\text { Share }\end{array}$ & Influences \\
\hline elonmusk & $17.078 \%$ & 115 Juta \\
bmurphypointman & $4.584 \%$ & 31 Juta \\
MeekMill & $2.485 \%$ & 17 Juta \\
cryptunez & $1.504 \%$ & 10 Juta \\
Cz_binance & $1.298 \%$ & 8.7 Juta \\
DailyDogeUpdate & $1.241 \%$ & 8.4 Juta \\
davidgokhshtein & $0.987 \%$ & 6.6 Juta \\
mcuban & $0.949 \%$ & 6.4 Juta \\
binance & $0.89 \%$ & 6.0 Juta \\
DogecoinRise & $0.831 \%$ & 5.6 Juta \\
\hline
\end{tabular}

Sumber : Hasil penelitian menggunakan tools Brand 24

Voice of share pada Brand24 adalah pengukuran visibilitas sebuah brand atau public profiles pada berbagai channels yang dihitung dari banyaknya mentions dan engagement seperti jumlah impressions, share, hashtags, dan reach dan membandingkannya dengan seluruh market sejenis (Marta, 2020). Sendangkan influences pada Brand24 merupakan kompilasi dari data followers, mentions, reach dan interactions atau engagements seorang public profiles pada media sosial (Tom, 2017). Sehingga dapat disimpulkan bahwa semakin besar angka voice of share dan influence seseorang artinya ia adalah public profiles yang memiliki pengaruh kuat pada sebuah komunitas di media sosial. Pada Tabel 4 terdapat daftar Top 10 Public Profiles pada komunitas Dogecoin.

Tidak hanya Elon Musk, seperti terlihat pada Tabel 4, terdapat public profiles lain seperti Changpeng Zhao dengan akun cz_binance yaitu CEO dari cryptocurrency Binance. Changpeng Zhao mengepos tweet yang menyatakan bahwa ia telah meremehkan beberapa cryptocurrency termasuk diantaranya adalah Dogecoin. Tweet tersebut berbunyi :

"I under estimated $\$ D O G E$, and \#ETH, and $\# B T C$, and \#BNB, and many more. Not financial advice."(CZ Binance, 2021)

Tweet dari Changpeng Zhao tersebut dapat diartikan bahwa ia ingin mengatakan bahwa Dogecoin setara dengan cryptocurrencies lainnya yang termasuk dalam urutan teratas dalam cruptocurrency market cap. Tentunya hal ini memberikan dukungan dan semangat kepada para investor Dogecoin. Tweet lainnya datang dari public profile bernama David Gokhshtein, yaitu seorang pengusaha dan Forbes Financial Council.

"Amazon thinking about accepting \$DOGE as payment according to @newsbtc." (David Gokhshtein, 2021)

Tweet dari David Gokhshtein tersebut juga memberikan konfirmasi bahwa Dogecoin mulai diperhitungkan secara serius oleh perusahaan besar seperti Amazon sebagai alat pembayaran transaksi. Selain itu terdapat tweet dari akun public profile seorang influencer Dogecoin @cryptunez:

"if \$DOGE goes over \$1 in the next 24 hours $i$ will give everyone that retweets this 1,000 \$DOGE."

(\$DOGE TO \$2 $\bigcirc(69 \mid \mathrm{I}), 2021)$ 
Tweet dari @cryptunez tersebut pada dasarnya ingin memberikan semangat dan harapan bahwa Dogecoin akan memiliki nilai tukar sebesar \$1 dalam waktu cepat. Kemudian seperti yang dijanjikan oleh @cryptunez bahwa ia akan memberikan sejumlah Dogecoin kepada semua orang yang retweet, maka banyak juga para influencers lain yang melakukan hal yang sama. Mereka mengadakan giveaway dengan memberikan sejumlah Dogecoin jika suatu kondisi terpenuhi, seperti retweet dan follow akun pemberi Dogecoin tersebut. Seperti terlihat pula pada Tabel 3 bahwa kata kunci give sering pula digunakan dalam tweet. Hal ini menunjukkan bahwa Dogecoin adalah crytocurrency yang diperhitungkan dan menjanjikan sehingga dapat menarik komunitas untuk mengikuti giveaway tersebut. Berikut adalah contoh tweet giveaway yang dilakukan oleh seorang micro -influencer dengan akun @ChairwomanDoge :

"NEWS ALERT : Reminder: At 10,000 followers I will be giving away $\$ 1000$ worth of $\$ D O G E$ to a lucky follower. Like, retweet and follow to be entered. One follower will be randomly chosen! This will be my last giveaway \#dogecoin." (DogeCoin Chairwoman, 2021)

\section{Pola Komunikasi Berdasar Struktur Jaringan Komunikasi}

Netnografi digital dapat memberikan pehamahan budaya dan kebiasaan berdasarkan pola yang dicari sesuai dengan tujuan penelitian. Pola tersebut dapat dilihat dari infastruktur jaringan sociocultural yang didapat dari hasil analisa data (Kozinets, 2018).

Pengambilan data melalui tools Netlytic telah memberikan data pengukuran struktur jaringan komunikasi komunitas Dogecoin di Twitter. Karena keterbatasan jenis akun Tier 2 yang dimiliki oleh peneliti maka setiap data set pada Netlytic hanya bisa menampung 10.000 mentions. Pada penelitian ini telah diambil beberapa data sets namun yang akan diambil sebagai sampel data analisa adalah penarikan data terkini yaitu pada akhir periode penelitian ini. Hal ini dikarenakan telah terjadi beberapa peristiwa sebelumnya yang tentunya akan memengaruhi pola komunikasi komunitas secara keseluruhan hingga akhir periode penelitian. Data yang dipakai adalah penarikan mentions pada Twitter untuk kata kunci Doge, dan berhasil menarik data sebanyak 10.000 mentions pada tanggal 9 Mei 2021.

Netlytic menyediakan beberapa fungsi untuk menganalisa struktur jaringan, diantaranya adalah network analysis berdasarkan dua tipe jaringan komunikasi yaitu chain network dan name network. Gruzd et al. (2016) menyatakan bahwa chain network menggambarkan relasi antar partisipan secara langsung dalam bentuk replies. Sedangkan name network dapat digunakan untuk melihat relasi antar partisipan dalam bentuk mentions nama atau nama akun pada media sosial.

Netlytic juga menyediakan visualisasi data jaringan seperti yang terlihat pada Gambar 1 dan 2. Sedangkan data pengukuran struktur jaringan ada pada Tabel 5 dan 6. Pada Gambar 1 terlihat visualisasi dari chain network yang memperlihatkan pola jaringan komunikasi yang didasarkan pada relasi dalam bentuk replies. Dapat dilihat pada gambar chain network tersebut terdapat 2 pola clusters yang terbentuk.

Pola clusters yang pertama yaitu adanya beberapa clusters besar di mana masing - masing cluster terdiri dari banyak nodes dan terpusat pada beberapa dominant actors. Para aktor yang mendominasi tersebut dapat terdiri dari public profiles ataupun influencers. Hal ini menunjukkan bahwa terjadi interaksi berupa replies dari para anggota komunitas 
terhadap tweets dari para public profiles dan influencers. Beberapa clusters yang terpusat tersebut dapat dilihat terletak pada pusat jaringan.

Sedangkan pola clusters yang kedua yaitu terdiri dari clusters kecil yang hanya terdiri dari 1-3 nodes dan tersebar secara bebas memenuhi jaringan serta tidak terpusat pada dominant actors tertentu. Hal ini menunjukkan bahwa terjadi interaksi bebas di mana para anggota komunitas saling mengepos tweets dan memberikan replies atas kemauan sendiri dan tidak diinisiasi oleh dominant actors pada jaringan.

Temuan pola clusters yang terlihat pada visualisasi jaringan tersebut juga didukung dengan data pengukuran struktur jaringan pada Tabel 5, yaitu pada properti centralization dan modularity. Nilai centralization yang tinggi, yaitu mendekati angka 1 menunjukkan bahwa interaksi terpusat pada dominant actors. Sedangkan jika jauh lebih rendah dari angka 1 artinya interaksi tidak terpusat dan dipengaruhi oleh dominant actors (Gruzd et al., 2016).

Kemudian menurut Gruzd et al. (2016) untuk nilai modularity yang rendah mendekati angka nol menunjukkan bahwa komunitas terdiri dari kelompok yang koheren dengan topik percakapan yang sama. Sebaliknya, menurut Prihantoro, Rakhman, \& Ramadhani (2021), nilai modularity yang tinggi mendekati angka 1 , menunjukkan bahwa komunitas tersebut telah terbagi menjadi kelompok atau clusters dengan topik pembicaraan yang berbeda dan dipengaruhi pula oleh dominant actors yang berbeda pada setiap cluster. Jika melihat Tabel 5, maka dapat dilihat bahwa pada chain network nilai centralization adalah 0.060260 dan modularity adalah 0.929600 . Nilai tersebut menunjukkan bahwa interaksi berupa replies pada komunitas Dogecoin tidak terpusat pada dominant actors dan terbagi dalam clusters yang beragam dengan topik percakapan yang berbeda - beda. Meskipun terdapat beberapa top public profiles pada komunitas Dogecoin, namun masing - masing anggota komunitas memiliki inisiatif untuk mengepos tweets dan memberikan replies tanpa menunggu adanya ajakan dan inisiasi dari top profiles.

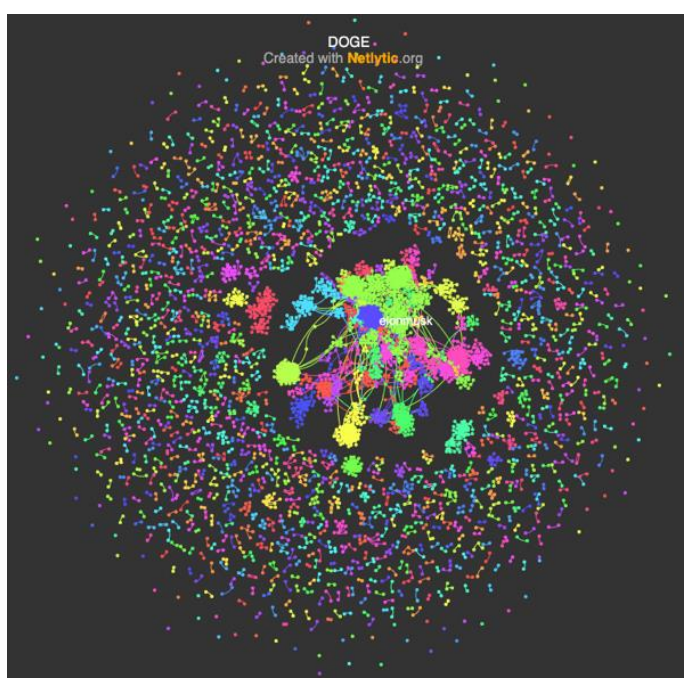

Gambar 1 Visualisasi Jaringan Komunikasi Dogecoin dengan struktur Chain Network

Sumber : Hasil penelitian menggunakan tools Netlytic

Tabel 5 Pengukuran Chain Network Dogecoin

\begin{tabular}{ll}
\hline Properti & Nilai \\
\hline Diameter & 11 \\
Density & 0.00014250 \\
Reciprocity & .045050 \\
Centralization & 0.060260 \\
Modularity & 0.929600 \\
\hline \multicolumn{2}{r}{ *Posters with ties $: 3.980$}
\end{tabular}

Sumber : Hasil penelitian menggunakan tools Netlytic

Selain itu terdapat pula pengukuran reciprocity, di mana jika nilai reciprocity adalah 1 artinya terdapat komunikasi dua arah antar semua nodes yang ada pada sebuah jaringan komunikasi, dan hal tersebut adalah kondisi yang hampir tidak pernah terjadi pada media sosial, dikarenakan jumlah nodes yang sangat banyak (Gruzd et al., 2016). Seperti terlihat 
pada Tabel 5 bahwa nilai reciprocity adalah 0.045050, maka dapat dikatakan bahwa nilai reciprocity mendekat angka o dan hal tersebut menunjukkan jarang terjadi komunikasi dua arah antar anggota komunitas. Dalam chain network komunitas Dogecoin, angka reciprocity yang rendah menunjukkan bahwa jika terdapat tweet maka hanya terdapat interaksi satu arah berupa reply kepada tweet tersebut, karena seringkali author dari tweet tersebut tidak merespon kembali. Hal ini dapat terjadi jika author adalah seorang public profiles dan mendapatkan banyak replies sehingga tidak memungkinkan untuk merespon semua replies yang ada dan berinteraksi lebih lanjut dengan mereka yang meberikan replies. Selain itu rendahnya reciprocity juga dapat memberikan konfirmasi untuk pernyataan Phillips \& Gorse (2018) bahwa banyak pengguna menggunakan media sosial Twitter hanya untuk mendapatkan informasi dan prediksi aset keuangan seperti cryptocurrency, dan bukan untuk bersosialisasi lebih lanjut dengan pengguna lainnya.

Selanjutnya terdapat properti diameter yaitu untuk mengukur jarak antar nodes terjauh dalam sebuah jaringan komunikasi. Diameter akan menghitung berapa nodes yang harus dilalui agar informasi dapat tersampaikan dengan menghitung jarak terpendek antara nodes terjauh (Gruzd et al., 2016). Nilai diameter dari chain network Dogecoin adalah 11, yang berarti diperlukan 11 nodes agar sebuah informasi dapat tersampaikan di antara nodes yang terjauh. Semakin tinggi angka density artinya akan diperlukan waktu lebih lama untuk persebaran sebuah informasi (Prihantoro et al., 2021).

Selain itu, properti density akan menghitung intensitas komunikasi yang terjadi di antara nodes dalam sebuah jaringan komunikasi (Samatan, Fatoni, \&
Murtiasih, 2020). Jika nilai density mendekati angka 1 maka menandakan tingginya intensitas komunikasi yang berarti setiap nodes berkomunikasi kepada hampir semua nodes lain yang ada pada jaringan (Gruzd et al., 2016). Jika melihat nilai density pada Tabel 5 yang rendah dan mendekati angka nol, menandakan rendahnya intensitas komunikasi chain network Dogecoin. Rendahnya density dapat berarti banyak anggota komunitas yang bukan merupakan dominant actors dan memiliki pengaruh kecil pada komunitas, sehingga tweets yang diposting tidak mendapat banyak respon dan interaksi dari anggota komunitas yang lainnya (Samatan et al., 2020). Jika melihat tingginya nilai diameter dan rendahnya density pada chain network Dogecon, maka dapat dikatakan bahwa sebagian besar anggota komunitas Dogecoin tidak saling mengenal satu sama lainnya pada dunia nyata dan berasal dari beragam latar belakang di seluruh penjuru dunia. Hal ini juga dapat menjadi sebab rendahnya nilai density yaitu adanya keseganan untuk berinteraksi karena tidak saling mengenal satu sama lainnya. Keseganan tersebut bisa jadi disebabkan karena budaya yang berbeda sehingga ada kekuatiran komunikasi tidak tersampaikan dengan baik (Tjahyana, 2020). Namun meskipun tidak saling mengenal sebelumnya, mereka memiliki semangat dan tujuan yang sama untuk saling mendukung dan memberikan semangat pada komunitas Dogecoin dengan mengepos tweet menggunakan hashtags yang dipakai pada komunitas Dogecoin. Dalam hal ini hastags yang dipakai merupakan cara untuk mengindentifikasikan diri sebagai anggota komunitas dan mempersatukan seluruh anggota komunitas yang tersebar dan tidak saling mengenal sebelumnya.

Peneliti sebagai netnografer mencoba untuk membuat co-created data berupa 
tweet dengan hashtags seputar Dogecoin, untuk melihat interaksi dari komunitas. Adapun co-created data dapat merupakan data yang didapat dari hasil interaksi dan percakapan antara netnografer dengan anggota komunitas (Kozinets, 2018). Berikut adalah tweet dari netnografer pada akun @joannetjia:

"\#DogecoinToTheMoon \#dogecoin waiting for the dip to buy again. "(Joanne Tjia, 2021)

Kemudian tweet tersebut mendapatkan reply dari akun yang tidak dikenal oleh netnografer dan bukan merupakan follower dari akun @joannetjia. Reply tersebut datang dari akun @RetiredC0857 yang pada dasarnya memberikan dukungan dan semangat untuk terus berharap Dogecoin akan tetap mengalami peningkatan nilai tukar. Tweet tersebut berbunyi:

"andy Grant @RetiredCo857 Replying to @joannetjia

Damn a dip !!! Go \#doge go 스."

(Randy Grant, 2021)

Co-created data yang dihasilkan dari interaksi peneliti sebagai netnografer tersebut membuktikan bahwa meskipun tidak saling mengenal, namun anggota komunitas dapat dipertemukan dengan hashtags dan saling memberikan dukungan serta semangat untuk terus menaruh keyakinan pada Dogecoin.

Selanjutnya dapat dilihat pada visualisasi name network Dogecoin pada Gambar 2, di mana terdapat kesamaan pola dengan chain network yaitu terdapat pola komunikasi yang terpusat pada dominant actors dan pola komunikasi antar nodes lain yang tersebar disekitarnya.

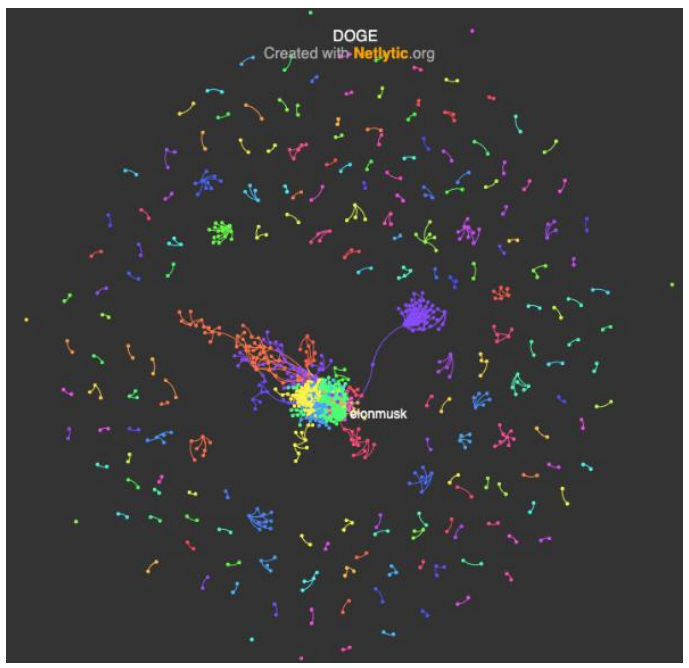

Gambar 2 Visualisasi Jaringan Komunikasi Dogecoin dengan struktur Name Network

Sumber : Hasil penelitian menggunakan tools Netlytic

Tabel 6 Pengukuran Name Network Dogecoin

\begin{tabular}{ll}
\hline Properti & Nilai \\
\hline Diameter & 6 \\
Density & 0.000827 \\
Reciprocity & 0.000000 \\
Centralization & 0.132500 \\
Modularity & 0.808500 \\
\hline \multicolumn{2}{c}{$*$ *Posters with ties $: 685$}
\end{tabular}

Sumber : Hasil penelitian menggunakan tools Netlytic

Namun jika dibandingkan dengan chain network pada Gambar 1, maka dapat terlihat bahwa persebaran nodes pada name network tidak sebanyak chain network. Hal ini sesuai dengan perbandingan data posters with ties dari name network hanya 685 sedangkan chain network sebanyak 3.980. Posters with ties adalah banyaknya nodes yang mengepos tweet dan mendapat interaksi dari nodes lainnya ("Network Analysis / Visualization Netlytic.Org," 2021). Jumlah posters with ties yang lebih sedikit pada name network menandakan bahwa tidak banyak anggota komunitas yang melakukan interaksi berupa mentions pada anggota lainnya. Hal ini mungkin terjadi karena tidak banyak anggota komunitas yang saling mengenal 
satu sama lainnya. Namun mentions banyak ditujukan kepada para dominant actors yang merupakan top public profiles maupun influencers pada komunitas Dogecoin. Hal tersebut didukung dengan data centralization yang dapat dilihat pada Tabel 6, di mana nilai centralization pada name network adalah 0.132500 , yaitu lebih tinggi dari nilai centralization pada chain network yaitu 0.060260 .

Kemudian nilai reciprocity pada name network adalah 0.000000 , di mana artinya hampir tidak terjadi komunikasi dua arah. Hal ini merupakan sesuatu yang wajar terjadi, karena mentions lebih banyak terpusat dan ditujukan pada dominant actors, dan tentunya tidak memungkinkan bagi para aktor dominan tersebut untuk membalas dan berinteraksi pada semua orang yang melakukan mentions kepada akun mereka. Sehingga komunikasi yang terjadi cenderung merupakan komunikasi satu arah berupa mentions yang tidak di respon kembali oleh para dominant actors.

Jika melihat visualisasi jaringan baik chain network pada Gambar 1 dan name network pada Gambar 2, maka dapat dilihat adanya beberapa dominant actors yang menjadi pusat percakapan. Salah satu dominant actor yang menonjol pada kedua network adalah Elon Musk. Hal ini sesuai dengan data pada Tabel 4 yaitu daftar Top 10 Public Profiles pada komunitas Dogecoin bahwa Elon Musk dengan akun Twitter @elonmusk, menduduki posisi pertama dari daftar tersebut. Elon Musk memang merupakan public profiles yang membawa pengaruh sangat signifikan pada pelonjakkan nilai tukar Dogecoin pada tahun 2021 yang terlihat dengan adanya beberapa tweet dari Elon Musk yang selalu disusul dengan kenaikan nilai tukar Dogecoin (Chohan, 2017). Pengaruh yang kuat tersebut membuat komunitas Dogecoin menaruh harapan kepada sosok Elon Musk untuk terus memberikan dukungan pada Dogecoin. Sehingga ketika Elon Musk mengepos tweet tentang Dogecoin, selalu mendapatkan interaksi berupa replies yang sangat banyak. Selain itu banyak anggota komunitas yang menunjukkan harapan kepada Elon Musk dengan cara mentions Elon Musk pada tweet mereka. Menurut data yang didapat menggunakan Brand24, terdapat 95.325 replies dan mentions kepada @elonmusk dengan kata kunci "Doge" pada periode 1 April - 9 Mei 2021. Berikut adalah contoh tweet yang memberikan mentions kepada Elon Musk dari akun @itsALLrisky :

"This \#DogeDay is dedicated to the man, the myth, the legend, the Technoking of Tesla, the Imperator of Mars, Destroyer of Shorts, Master of Memes, King of Twitter, Humanity's Best, the one and only:

@ElonMusk!

On behalf of all of Us, THANK YOU! \#DogeDay420 \#Doge \#420day \#Doge420"

(itsALLrisky, 2021)

Tweet dari @itsALLrisky tersebut telah memperoleh banyak interaksi berupa likes dan retweets dari komunitas, yang ditandai dengan influencer score pada Brand 24 sebesar 9/10.

Berikut adalah contoh tweet yang merupakan reply kepada salah satu tweet dari Elon Musk, dari akun @blakestonks :

"@blakestonks Replying to @elonmusk

if doge goes to the moon elon, $i$ will buy my mom a tesla. I love you" (blake, 2021)

Tweet dari @blakestonks tersebut telah memperoleh cukup banyak likes dan retweet dari komunitas, yang ditandai dengan influencer score pada Brand 24 sebesar 3/10.
Pola Komunikasi Jaringan
Cryptocurrency Dogecoin di Twitter 
Berdasarkan observasi dan analisa maka telah didapatkan pola komunikasi jaringan cryptocurrency Dogecoin pada Twitter. Pola komunikasi ini dibagi menjadi beberapa tipe berdasarkan urutan dan jenis interaksi yang dilakukan oleh komunitas.

Tipe interaksi pertama yaitu tahap mengidentifikasikan diri sebagai anggota komunitas Dogecoin dengan cara mengepos tweet menggunakan hashtags seputar Dogecoin seperti \#Doge, \#Dogecoin, \#Dogearmy, dan masih banyak lagi seperti yang dapat dilihat pada Tabel 1. Selain hashtags dapat juga menggunakan cashtags seperti \$Doge atau $\$$ Dogeocoin seperti yang dapat dilihat pada Tabel 2.

Tipe interaksi kedua yaitu memberikan dukungan dan semangat kepada sesama anggota komunitas Dogecoin dengan cara mengepos tweets dengan kata kunci dan hashtags yang bertujuan memberikan harapan dan semangat seperti moon, buy, pump, hold, hodl, spaceX, \#Dogeday, \#Dogecointothemoon, \#Dogefather, dan masih banyak lagi seperti yang dapat dilihat pada Tabel 1 dan Tabel 3 .

Tipe interaksi ini juga bertujuan untuk memberikan pengetahuan dan konfirmasi tentang Dogecoin kepada sesama anggota komunitas. Selain itu banyak pula yang menggunakan tweet untuk mencurahkan perasaan dan emosi pada komunitas terutama jika mendapat banyak keuntungan ataupun saat mengalami kerugian.

Tipe interaksi ketiga yaitu berinteraksi dengan memberikan replies kepada tweets anggota komunitas lainnya, yang banyak terjadi secara satu arah karena tidak saling mengenal, dengan tujuan memberikan semangat dan dukungan.

Tipe interaksi keempat yaitu berinteraksi dengan memberikan mentions dan replies berisi harapan kepada para top public profiles yang dipercaya dapat membawa peningkatan pada nilai tukar Dogecoin, seperti mentions yang banyak ditujukan kepada Elon Musk. Tipe interaksi ini juga banyak terjadi secara satu arah karena tidak adanya balasan dan interaksi lebih lanjut dari para top public profiles.

Tipe interaksi kelima yaitu interaksi antara top public profiles untuk memberikan semangat, dukungan dan konfirmasi kepada anggota komunitas untuk terus mempertahankan Dogecoin. Banyak pula terdapat tweet yang merupakan giveaway Dogecoin dari para top public profiles kepada anggota komuntas. Tipe interaksi ini banyak terjadi secara satu arah karena tidak adanya balasan atau diskusi lebih lanjut dari top public profiles kepada mereka yang memberikan replies pada tweet mereka.

\section{Kesimpulan}

Pola komunikasi yang terjadi pada jaringan komunitas Dogecoin di Twitter dimotivasi oleh faktor - faktor yang membentuk sense of community. Pola yang terlihat ketika memulai percakapan adalah dengan melakukan identifikasi diri sebagai anggota komunitas menggunakan hashtags, cashtags, dan kata kunci seputar Dogecoin pada tweet yang diposting. Komunitas Dogecoin pada Twitter tidak terpusat pada akun - akun komunitas tertentu, namun semua individu dapat menjadi bagian dari komunitas dengan aktif berdiskusi tentang Dogecoin. Oleh karena itu identifikasi diri akan selalu dilakukan setiap kali memulai percakapan pada komunitas.

Kemudian dikarenakan volatility yang tinggi dari nilai tukar Dogecoin maka komunitas menjadi sarana untuk mencari prediksi dan konfirmasi pergerakan nilai tukar Dogecoin. Selain itu komunitas menjadi tempat untuk mencurahkan emosi 
dan perasaan ketika mengalami kerugian atau mendapat banyak keuntungan saat aktivitas trading Dogecoin. Hal itu nampak dari pola komunikasi pada komunitas di mana mereka saling berinteraksi dengan memberikan dukungan dan semangat agar tetap hold Dogecoin yang dimiliki. Komunikasi tersebut dilakukan dalam bentuk postingan tweet serta like dan reply untuk merespon tweet dari anggota komunitas lainnya.

Selain itu, peran top public profiles cukup penting dalam menggerakan sentimen percakapan pada komunitas. Hal ini dapat terlihat dengan banyaknya interaksi berupa replies dan mentions yang diberikan oleh komunitas kepada para top public profiles. Komunitas seringkali menyampaikan harapan mereka kepada top public profiles untuk menggunakan pengaruh mereka dalam meningkatkan nilai tukar Dogecoin. Para top public profiles juga ikut memberikan dukungan, semangat dan konfirmasi kepada komunitas agar mempertahankan dan tidak menjual Dogecoin meskipun nilai tukar sedang mengalami penurunan. Namun demikian interaksi yang terjadi tidak tergantung sepenuhnya pada tweet dari top public profiles karena banyak clusters kecil percakapan yang tersebar luas pada jaringan dan diinisisasi dengan sendirinya oleh setiap individu yang ada pada komunitas.

Adapun pola komunikasi yang terjadi pada jaringan komunitas Dogecoin lebih bersifat satu arah dan tidak berlanjut kepada percakapan yang lebih dalam untuk mengenal satu sama lainnya. Hal ini disebabkan karena banyak anggota komunitas yang hanya menggunakan Twitter sebagai sarana untuk mencari informasi, prediksi dan konfirmasi perkembangan Dogecoin. Mereka tidak berminat untuk bersosialiasi lebih lanjut dengan anggota komunitas yang lain.
Selain itu anggota komunitas terdiri dari berbagai latar belakang di seluruh dunia, sehingga perbedaan budaya juga merupakan hambatan terjadinya komunikasi lebih dalam di antara mereka.

Saran yang dapat diberikan kepada pengembang Dogecoin dan cryptocurrency lainnya adalah pentingnya membina komunitas pada Twitter dengan memberikan informasi yang bermanfaat berupa berita terkini, prediksi nilai tukar dan konfirmasi yang dapat menjawab keresahan terkait volatility yang tinggi dari sebuah cryptocurrency. Kemudian dapat pula membuat hashtags tertentu yang dapat membantu menggerakan percakapan. Selain itu dapat bekerjasama dengan top public profiles untuk menggerakan sentimen komunitas dan meyakinkan komunitas untuk berinvestasi pada cryptocurrency tersebut. Untuk meningkatkan interaktifitas agar komunikasi tidak cenderung satu arah adalah dengan membuat akun-akun cryptocurrency dalam beberapa bahasa selain bahasa Inggris untuk mengatasi hambatan budaya dan memberikan rasa nyaman dalam berkomunikasi.

\section{Referensi}

\$DOGE TO \$2 $O$ (6glQ). (2021, May 7). If $\$ D O G E$ goes over $\$ 1$ in the next 24 hours i will give everyone that retweets this 1,000 \$DOGE [Tweet]. Retrieved May 12, 2021, from @cryptunez website: https://twitter.com/cryptunez/stat us/1390658509835018243

Abraham, J., Higdon, D., Nelson, J., \& Ibarra, J. (2018). Cryptocurrency Price Prediction Using Tweet Volumes and Sentiment Analysis. 1(3), 22.

Annisa, S. (2019). STUDI NETNOGRAFI

PADA AKSI BEAT PLASTIC

POLLUTION OLEH UNITED

NATIONS ENVIRONMENT DI

MEDIA SOSIAL INSTAGRAM. Jurnal ASPIKOM, 3(6), 1109-1123. 
https://doi.org/10.24329/aspikom. v3i6.411

Aslantas, S. (2021, April 29). Dogecoin (DOGE): Is The Hype Real? Will Hit to $\$ 1$ ? Retrieved May 5, 2021, from Medium website: https://medium.com/coinmonks/d ogecoin-doge-is-the-hype-realwill-hit-to-1-1badd32646db BEN BALLER ${ }^{\text {TM }}$. (2021, April 17). YALL THOUGHT I SOLD!!! NO I DID NOT. EVEN AFTER WE HIT \$1.00 USD I WILL NOT SELL! 1. \#HODL 2. Coinbase will pick up \#Doge 3. Elon will take a \#Dogecoin to the moon. 4. We aiming for over $\$ 1.00$ \#DogeArmy stop playing! Everyone HODL! [Tweet]. Retrieved May 12, 2021, from @BENBALLER website: https://twitter.com/BENBALLER/st atus/1383503713025683459

blake. (2021, April 17). @elonmusk if doge goes to the moon elon, i will buy my mom a tesla. I love you [Tweet]. Retrieved May 15, 2021, from @blakestonks website: https://twitter.com/blakestonks/st atus/1383233305579966469

Bright, J. (2018). Explaining the

Emergence of Political Fragmentation on Social Media: The Role of Ideology and Extremism. Journal of ComputerMediated Communication, 23(1), 17-33. https://doi.org/10.1093/jcmc/zmxo 02

Browne, R. (2021a, April 16). Dogecoin spikes $400 \%$ in a week, stoking fears of a cryptocurrency bubble. Retrieved May 1, 2021, from CNBC website: https://www.cnbc.com/2021/04/16 /dogecoin-doge-price-memecryptocurrencys-rise-sparksbubble-fears.html

Browne, R. (2021b, April 28). Dogecoin price surges after tweets from Elon Musk and Mark Cuban. Retrieved May 4, 2021, from CNBC website: https://www.cnbc.com/2021/04/28 /dogecoin-price-surges-after- tweets-from-elon-musk-andmark-cuban.html

Chatterjee, R., \& Correia, A.-P. (2020). Online Students' Attitudes Toward Collaborative Learning and Sense of Community. American Journal of Distance Education, 34(1), 53-68. https://doi.org/10.1080/08923647. 2020.1703479

Chohan, U. W. (2017). A History of Dogecoin. SSRN Electronic Journal. https://doi.org/10.2139/ssrn.30912 19

$C Z \diamond$ Binance. (2021, May 4). I under estimated $\$ D O G E$, and $\# E T H$, and \#BTC, and \#BNB, and many more. Not financial advice. [Tweet]. Retrieved May 12, 2021, from @cz_binance website: https://twitter.com/cz_binance/sta tus/1389619160812986369

David Gokhshtein. (2021, April 20). Amazon thinking about accepting \$DOGE as payment according to @newsbtc. [Tweet]. Retrieved May 12, 2021, from @ davidgokhshtein website: https://twitter.com/davidgokhshte in/status/1384549790311227395

Del Vecchio, P., Mele, G., Passiante, G., Vrontis, D., \& Fanuli, C. (2020). Detecting customers knowledge from social media big data:

Toward an integrated methodological framework based on netnography and business analytics. Journal of Knowledge Management, 24(4), 799-821. https://doi.org/10.1108/JKM-112019-0637

Dogecoin. (2021, April 18). \#Doge-Buy the dip $\bigcirc$ \#Dogecoin [Tweet]. Retrieved May 15, 2021, from @Investments_CEO website: https://twitter.com/Investments_C EO/status/1383579890448945157

DogeCoin Chairwoman. (2021, April 23). NEWS ALERT 2 : Reminder: At 10,000 followers I will be giving away $\$ 1000$ worth of \$DOGE to a lucky follower. Like, retweet and follow to be entered. One follower will be randomly chosen! This will 
be my last giveaway 6

\#dogecoin [Tweet]. Retrieved May

12, 2021, from

@ChairwomanDoge website:

https://twitter.com/ChairwomanD

oge/status/1385468289049006083

Elon Musk. (2021a, April 28). The

Dogefather SNL May 8 [Tweet].

Retrieved May 12, 2021, from

@elonmusk website:

https://twitter.com/elonmusk/stat

us/1387290679794089986

Elon Musk. (2021b, May 9). SpaceX

launching satellite Doge- 1 to the

moon next year - Mission paid for

in Doge - 1st crypto in space - 1st

meme in space To the

mooooonnn!!

Https://t.co/XXfjGZVeUW [Tweet].

Retrieved May 12, 2021, from

@elonmusk website:

https://twitter.com/elonmusk/stat

us/1391523807148527620

Eriyanto. (2014). Analisis Jaringan

Komunikasi: Strategi Baru dalam

Penelitian Ilmu Komunikasi dan

Ilmu Sosial Lainnya. Jakarta:

Prenadamedia Group.

Evans, L., Owda, M., Crockett, K., \& Vilas,

A. F. (2019). A methodology for

the resolution of cashtag collisions

on Twitter - A natural language

processing \& data fusion

approach. Expert Systems with

Applications, 127, 353-369.

https://doi.org/10.1016/j.eswa.201

9.03.019

Frankenfield, J. (2020). HODL. Retrieved

May 12, 2021, from Investopedia

website:

https://www.investopedia.com/ter $\mathrm{ms} / \mathrm{h} /$ hodl.asp

Gibbs, J. L., Kim, H., \& Ki, S. (2019).

Investigating the Role of Control

and Support Mechanisms in

Members' Sense of Virtual

Community. Communication

Research, 46(1), 117-145.

https://doi.org/10.1177/009365021

6644023

Gotter, A. (2019, October 17). 23

Strategies to Increase Your Twitter

Engagement. Retrieved May 15,
2021, from AdEspresso website:

https://adespresso.com/blog/23-

strategies-increase-twitter-

engagement/

Gruzd, A., Paulin, D., \& Haythornthwaite,

C. (2016). Analyzing Social Media

and Learning Through Content

and Social Network Analysis: A

Faceted Methodological

Approach. Journal of Learning

Analytics, 3(3), 46-71.

https://doi.org/10.18608/jla.2016.3

3.4

Irwan, \& Indrawan, A. (2021, April 17).

Wow! Dogecoin Investment

Continues To Skyrocket Up To 300

Percent [News]. Retrieved May 27,

2021, from VOI - Waktunya

Merevolusi Pemberitaan website:

https://voi.id/en/technology/45149

/wow-dogecoin-investment-

continues-to-skyrocket-up-to-30opercent

itsALLrisky. (2021, April 20). This

\#DogeDay is dedicated to the

man, the myth, the legend, the

Technoking of Tesla, the

Imperator of Mars, Destroyer of

Shorts, Master of Memes, King of

Twitter, Humanity's Best, the one

and only: @ElonMusk! On behalf

of all of Us, THANK YOU!

\#DogeDay420 \#Doge \#42oday

\#Doge420 https://t.co/JddJToYItg

[Tweet]. Retrieved May 15, 2021,

from @itsALLrisky website:

https://twitter.com/itsALLrisky/sta

tus/1384381034687393793

Joanne Tjia. (2021, April 16).

\#DogecoinToTheMoon \#dogecoin waiting for the dip to buy again

内人 https://t.co/GUSWcd48Tz

[Tweet]. Retrieved May 15, 2021,

from @joannetjia website:

https://twitter.com/joannetjia/stat

us $/ 1382885303363403780$

Klein, T., Pham Thu, H., \& Walther, T.

(2018). Bitcoin is not the New Gold

- A comparison of volatility,

correlation, and portfolio

performance. International Review

of Financial Analysis, 59, 105-116. 
https://doi.org/10.1016/j.irfa.2018. 07.010

Kozinets, R. V. (2018). Netnography for Management and Business Research. In C. Cassell, A. L. Cunliffe, \& G. Grandy, The SAGE Handbook of Qualitative Business and Management Research Methods: Methods and Challenges. SAGE Publications Ltd.

Kraaijeveld, O., \& De Smedt, J. (2020). The predictive power of public Twitter sentiment for forecasting cryptocurrency prices. Journal of International Financial Markets, Institutions and Money, 65. https://doi.org/10.1016/j.intfin.202 0.101188

Lizzo, R., \& Liechty, T. (2020). The Hogwarts Running Club and Sense of Community: A Netnography of a Virtual Community. Leisure Sciences, 1-18. https://doi.org/10.1080/01490400. 2020.1755751

Marta. (2020, July 20). How to measure the share of voice? | Brand24 Blog. Retrieved May 12, 2021, from https://brand24.com/blog/how-tomeasure-the-share-of-voice/

Mirtaheri, M., Abu-El-Haija, S., Morstatter, F., Steeg, G. V., \& Galstyan, A. (2019). Identifying and Analyzing Cryptocurrency Manipulations in Social Media. ArXiv:1902.03110 [Cs, Stat]. Retrieved from http://arxiv.org/abs/1902.03110

Mitchell, C. (2021). Buy The Dips Definition and Examples. Retrieved May 12, 2021, from Investopedia website: https://www.investopedia.com/ter $\mathrm{ms} / \mathrm{b} / \mathrm{buy}$-the-dips.asp

Morais, G. M., Santos, V. F., \& Gonçalves, C. A. (2020). Netnography: Origins, foundations, evolution and axiological and methodological development and trends. The Qualitative Report, 25(2), 441-445. https://doi.org/10.46743/21603715/2020.4227

Murdock, J. (2021, April 21). Dogecoin drops 20 percent despite fans'
"Doge Day" attempts to push up price. Retrieved May 28, 2021, from Newsweek website: https://www.newsweek.com/doge coin-cryptocurrency-drops-20percent-doge-day-price-rally-fails1585265

Naranjo-Zolotov, M., Oliveira, T., Casteleyn, S., \& Irani, Z. (2019). Continuous usage of eparticipation: The role of the sense of virtual community. Government Information Quarterly, 36(3), 536-

545 .

https://doi.org/10.1016/j.giq.2019. 05.009

Network Analysis / Visualization Netlytic.org. (2021). Retrieved June 1, 2021, from https://netlytic.org/home/?page_id $=2$

Park, H. W., \& Lee, Y. (2019). How Are Twitter Activities Related to Top Cryptocurrencies' Performance? Evidence from Social Media Network and Sentiment Analysis. Drustvena Istrazivanja, 28(3), 435460. https://doi.org/10.5559/di.28.3.04

Pathak, X., \& Pathak-Shelat, M. (2017). Sentiment analysis of virtual brand communities for effective tribal marketing. Journal of Research in Interactive Marketing, 11(1), 16-38. https://doi.org/10.1108/JRIM-o92015-0069

Phillips, R. C., \& Gorse, D. (2018). MutualExcitation of Cryptocurrency Market Returns and Social Media Topics. Proceedings of the 4 th International Conference on Frontiers of Educational Technologies - ICFET'18, 80-86. Moscow, Russian Federation: ACM Press. https://doi.org/10.1145/3233347.32 33370

Pound, J. (2021, May 5). Dogecoin jumps above 60 cents as speculative trading in crypto continues. Retrieved June 1, 2021, from CNBC website: https://www.cnbc.com/2021/05/05 
/dogecoin-is-surging-another-

zopercent-and-is-now-

approaching-70-cents-per-

coin.html

Prihantoro, E., Rakhman, F. R., \&

Ramadhani, R. W. (2021). Digital

Movement of Opinion

Mobilization: SNA Study on

\#Dirumahaja Vs. \#Pakaimasker.

Jurnal ASPIKOM, 6(1), 77.

https://doi.org/10.24329/aspikom.

v6i1.838

Priyowidodo, G. (2019). MONOGRAF

NETNOGRAFI KOMUNIKASI :

Aplikasi Pada Tiga Riset Lapangan.

Jakarta: Rajawali Pers.

Randy Grant. (2021, April 16). @joannetjia

Damn a dip !!! Go \#doge go (2)

[Tweet]. Retrieved May 15, 2021,

from @RetiredCo857 website:

https://twitter.com/RetiredCo857/s

tatus/1382885683598086148

Samatan, N., Fatoni, A., \& Murtiasih, S.

(2020). DISASTER

COMMUNICATION PATTERNS

AND BEHAVIORS ON SOCIAL

MEDIA: A STUDY SOCIAL

NETWORK \#BANJIR2020 ON

TWITTER: (Social Network

Analysis \#Banjir2020 on Twitter).

Humanities \& Social Sciences

Reviews, 8(4), 27-36.

https://doi.org/10.18510/hssr.2020.

844

Tana, S., Breidbach, C., \& Turpin, A.

(2019). I WANT A LAMBORGHINI:

AN ETHNOG'PHY OF

CRYPTOCURRENCY

COMMUNITIES. Proceedings of the

27th European Conference on

Information Systems (ECIS), 13.

Stockholm \& Uppsala, Sweden:

Association or Information

Systems. Retrieved from

https://aisel.aisnet.org/ecis2019_ri

$\mathrm{p} / 21$

Tjahyana, L. J. (2020). GERAKAN OPINI

DIGITAL \#TRUEBEAUTY PADA
TWITTER UNTUK PEMERAN FILM ADAPTASI KOMIK WEBTOON.

SOURCE : Jurnal Ilmu Komunikasi,

6(1), 34 .

https://doi.org/10.35308/source.v6i

1.1759

Tom. (2017, March 28). How the Top 100 Influencers Report Was Created | Brand 24 Blog. Retrieved May 12, 2021, from https://brand24.com/blog/howwe-created-a-data-based-report/

Voell, Z., \& Reynolds, K. (2021, January 28). Hot DOGE! Meme-Based Cryptocurrency Soars More Than $800 \%$ to Record High. Retrieved May 2, 2021, from CoinDesk website:

https://www.coindesk.com/dogec oin-price-record-high

Who can see your Tweets - Twitter privacy and protection settings. (2021).

Retrieved May 31, 2021, from https://help.twitter.com/en/safetyand-security/public-andprotected-tweets

Wilson, T., Irrera, A., \& Chavez-dreyfuss, G. (2021, April 20). Dogecoin cryptocurrency slumps after hashtag-fueled surge to record high. Retrieved May 5, 2021, from Reuters website:

https://www.reuters.com/technolo gy/dogeday-hashtags-help-memebased-cryptocurrency-dogecoinhit-new-high-2021-04-20/

Zhu, X., Benjamin, V., Qinglai, $H_{\text {., }}$ Department of Information Systems, Department of Supply Chain Management, \& Barrett, The Honors College. (2018). Twitter Sentiment Analysis For Bitcoin Price Prediction. In Academic Year 2018-2019. Barrett, The Honors College Thesis/Creative Project Collection. Retrieved from http://hdl.handle.net/2286/R.I.508 47 